\title{
El-Fayah
}

JURNAL BIOLOGI

Journal Homepage: http://ejournal.uin-malang.ac.id/index.php/bio/index

e-ISSN: 2460-7207, p-ISSN: 2086-0064

\section{Study of Population and Diversity of Diurnal Avifauna in Coban Tarzan and Coban Kodok Malang-East Java: an Inspiration From Holy Qur'an}

\section{Mujahidin Ahmad, Berry Fakhry Hanifa, Rizky Mujahidin Mulyono, Mohammad Ahlim Ihsan Abidin, Yudha Setya Pranata}

Department of Biology, Faculty of Science and Technology, Maulana Malik Ibrahim State Islamic University, Malang

*Corresponding author

Email: mujahidin@biologi.uin-malang.ac.id

DOI: 10.18860/elha.v8i1.11321

\begin{tabular}{l} 
A r t i c l e I n f o \\
\hline Article history: \\
Received 13 january 2020 \\
Received in revised form \\
24 march 2020 \\
Accepted 02 may 2020 \\
\hline Key Word: \\
Avifauna diurnal, \\
Coban Kodok, \\
Coban Tarzan, \\
Diversity, \\
Evenness, \\
dominance Index
\end{tabular}

\section{INTRODUCTION}

Birds are one part of biodiversity that is very important for an economic, recreational and scientific purposes (Calimpong and Nuneza, 2015; Hernowo and Prasetyo, 1989). For centuries birds have been a source of inspiration and provide pleasure to Indonesians because of their beauty. The list of birds in Indonesia (DBI) number 2 recorded that 1,598 of bird species found in Indonesia (Sukmantoro and Irham, 2007). This makes Indonesia the $4^{\text {th }}$ richest country in the world by the number of bird species after Columbia, Brazil and Peru As many as 372 species are endemic birds and 149 species are migratory birds Ironically, in Indonesia there are also 118 species of endangered birds according to the IUCN Red list (Sukmantoro and Irham, 2007). 
birds are creatures that have a quite special position in the Holy Qur'an. The mention of birds in the Holy Qur'an takes two forms; namely using general and specific terms. In special terms, there are three species of birds mentioned, namely the quail, the crow and the hoopoe. While in general the words bird are mentioned 12 times as in the following table 1.

Tabel 1. Birds Mentioned in Holy Qur'an

\begin{tabular}{|c|c|c|c|c|c|}
\hline No & Surah Name & Chapter & Verses & $\begin{array}{c}\text { Number of } \\
\text { Citation }\end{array}$ & Form of Citation \\
\hline \multirow[t]{2}{*}{1} & Al Baqarah & 2 & 260 & 1 & General \\
\hline & & 2 & 57 & 1 & Specific/Salwa/Quail \\
\hline 2 & Al Imran & 3 & 49 & 2 & General \\
\hline \multirow[t]{2}{*}{3} & Al Maidah & 5 & 11 & 4 & General \\
\hline & & 5 & 31 & 1 & Specific/Ghurab/Crow \\
\hline 4 & Al An'am & 6 & 38 & 1 & General \\
\hline 5 & Yusuf & 12 & 36,41 & 2 & General \\
\hline 6 & An Nahl & 16 & 79 & 1 & General \\
\hline 7 & Al Anbiya & 21 & 79 & 1 & General \\
\hline 8 & An Nur & 24 & 41 & 1 & General \\
\hline \multirow[t]{2}{*}{9} & An Naml & 27 & 20 & 1 & General \\
\hline & & 27 & $22-24$ & 1 & Specific/Hud-hud/Hoopoe \\
\hline 10 & Al Waqiah & 56 & 21 & 1 & General \\
\hline 11 & Al Mulk & 67 & 19 & 1 & General \\
\hline 12 & Al Fil & 105 & 3 & 1 & General \\
\hline 13 & Al-A'raf & 7 & 160 & 1 & Specific/Salwa/Quail \\
\hline 14 & Thaha & 20 & 80 & 1 & Specific/Salwa/Quail \\
\hline
\end{tabular}

(Islam and Sofiah, 2014)

In essence, the mention of birds in the Qur'an in various contexts is aimed at showing the omnipotence of Allah SWT and the importance of believing in the greatness of Allah subhanahu wa ta'ala as the creator and regulator of the universe. Humans are required to give thanks to Allah Subhanahu wa ta'ala and be responsible for all the favors received when he lives in this world as well as possible.

The results of the study also stated that birds have a very important role in the chain of ecosystems; they can function as pollinators, as predators, as pest eaters, insectivores and also as seed dispersers that cause plants to grow in various regions of the earth.Bird species are very diverse and each species is unique and of high value in terms of ecology, science, tourism and culture. Bird species can interact with each other and are scattered in their respective communities (Wisnubudi,
2009; Alikorda, 1990). Ghifari, et al. (2016) stated that birds have a reciprocal relationship and are interdependent with their environment, and analysis of biotic components, especially birds in the ecosystem, is important so that biological responses to environmental changes due to environmental quality degradation are known (Ghifari, et al., 2016) so that birds can be used as indicators of environmental quality change (Nugroho, 2008).

Research on birds is very interesting because birds are dynamic and can be an indicator of changes in the environment in which they are located. Based on this background, as well as considering the absence of data on bird diversity in the Coban Kodok and Coban Tarzan areas, in the context of preservation and management effectiveness, it is deemed necessary to 
conduct a study on the diversity of bird species in the Coban Kodok and Coban Tarzan areas.

\section{MATERIALS AND METHODS}

Data were collected using the Encounter Rate method (Bibby, 2000) with a predetermined path and time of observation. The data includes the image (photo), the type and number of birds are processed to determine the bird species diversity index value. This research was conducted in October -November 2019. Data collection on bird diversity was carried out in Coban Kodok, Pujon and Coban Tarzan, Tumpang District, Malang Regency (see Figure 1).

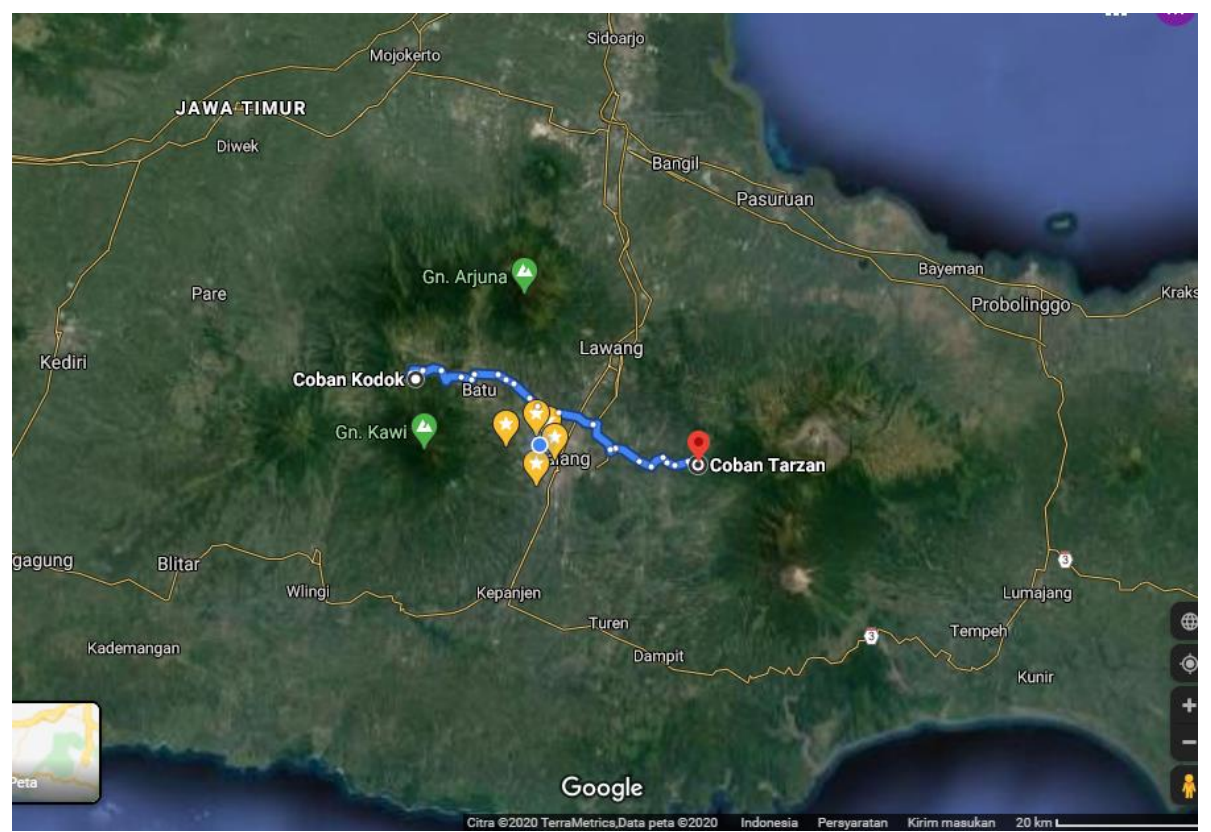

Figure 1. Satellite image of the location of reserach (Googlemap, 2020)

\section{Tools and Materials}

The tools used in this study were digital cameras, binoculars, GPS (global positioning system), compasses, voice recorders, meter tapes, raffia ropes, paper work, pencils, pens, markers, bird identification field manuals McKinnon et al., 2010). The materials used in this study were bird's photograph and voice.

\section{Research Methods}

Diurnal bird observations were conducted at 5-8.30 am and in the afternoon at 3-5.30 pm based on McKinnon et al., 2010. In this study, birds were counted from a fixed raising position within a circle of $50 \mathrm{~m}$ radius for a specific period of time (10 $\mathrm{min}$ ) at every point. After 5-min settling period, all birds seen and heard within this $50 \mathrm{~m}$ radius were recorded during the $10 \mathrm{~min}$. Observations were conducted with the aid of a camera with a 300 $\mathrm{mm}$ lens and were matched with the field manual book of MacKinnon et al. (2010). Observations were made with three repetitions on the line of observation. Observation data, namely the type, number, bird activity, temperature, humidity are used and entered into the daily table of bird observations, as well as the height of the location.

\section{Data Collection and Analysis}

Data include of birds number (abundance) were counted, photograph and image capture were collected and determined for each species using McKinnon (2010) field guide, and counted the species richness. Then the 
parameters include; Diversity Index, Evenness Index, and the Dominance Index were anlyzed using PAST software version 4.3. Data were interpreted and explained descriptively and discussed with the related refference.

\section{RESULTS}

Based on observations at the Coban Tarzan research location, 17 bird species were found as shown in Table 2.

Table 2. List of Avifauna Species at Coban Tarzan

\begin{tabular}{|c|c|c|c|c|}
\hline No & Local Name (Species name) & Ordo & Family & $\sum_{\text {rate }}$ encounter \\
\hline 1 & Elang ular bido (Spilornis cheela) & Accipitriformes & Accipitridae & 3 \\
\hline 2 & Walet linchi (Collocalia linchi) & Apodiformes & Apodidae & 37 \\
\hline 3 & Tekukur biasa (Streptopelia chinensis) & Columbiformes & Columbidae & 13 \\
\hline 4 & Cekakak jawa (Halcyon cyanoventris) & Coraciiformes & Alcedinidae & 1 \\
\hline 5 & Cekakak sungai (Todirhampus chloris) & Coraciiformes & Alcedinidae & 4 \\
\hline 6 & Kadalan Birah (Phaenicophaeus curvirostris) & Cuculiformes & Cuculidae & 1 \\
\hline 7 & Bentet kelabu (Lanius schach) & Passeriformes & Laniidae & 2 \\
\hline 8 & Bondol jawa (Lonchura leucogastroides) & Passeriformes & Estrildidae & 6 \\
\hline 9 & Kaca mata biasa (Zosterops palpebrosus) & Passeriformes & Zosteropidae & 2 \\
\hline 10 & Ciung batu (Myophonus caeruleus) & Passeriformes & Turdidae & 2 \\
\hline 11 & Cucak kutilang (Pycnonotus aurigaster) & Passeriformes & Pycnonotidae & 37 \\
\hline 12 & Kapasan kemiri (Lalage nigra) & Passeriformes & Campephagidae & 3 \\
\hline 13 & Madu sriganti (Nectarinia jugularis) & Passeriformes & Nectariniidae & 6 \\
\hline 14 & Merbah cerukcuk (Pycnonotus goaivier) & Passeriformes & Pycnonotidae & 20 \\
\hline 15 & Sepah kecil (Pericrocotus cinnamoneus) & Passeriformes & Campephagidae & 2 \\
\hline 16 & Ayam hutan merah (Gallus gallus) & Galliformes & Phasianidae & 2 \\
\hline \multirow[t]{2}{*}{17} & Caladi tilik (Dendrocopos moluccensis) & Piciformes & Picidae & 1 \\
\hline & Total & 8 & 14 & 142 \\
\hline
\end{tabular}
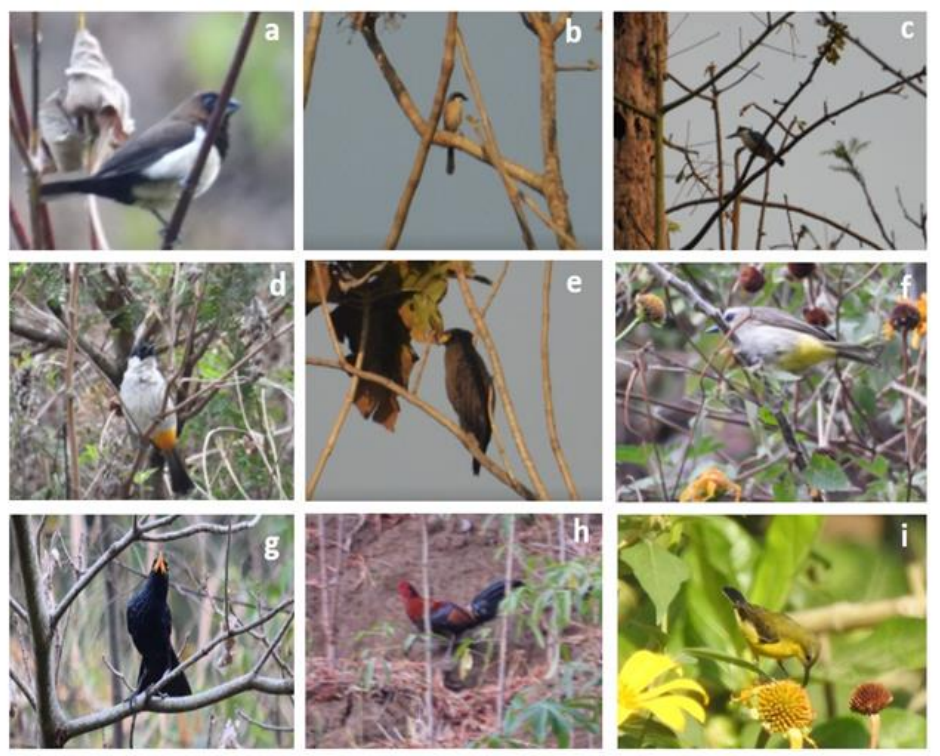

Figure 2 . Some of the observed species in coban tarzan, from left to right, top to bottom: a. Bondol jawa (Lonchura leucogastroides), b. Bentet Kelabu (Lanius schach), c Cekakak Sungai (Todiramphus chloris), d. Cucak kutilang (Pycnonotus aurigaster), e. Elang ular bido (Spilornis cheela), f. Merbah cerukcuk (Pycnonotus goaivier), g. Ciung batu siul (Myophonus caeruleus), h. Ayam hutan merah (Gallus gallus), dan i. Burung madu sriganti (Nectarinia jugularis). 
The results of observations in Coban Kodok obtained as shown in Table 3 below:

Table 3. List of Avifauna Species at Coban Kodok

\begin{tabular}{lllll}
\hline No & Local Name (Species name) & Ordo & Family & Zencounter rate \\
\hline 1 & Elang hitam (Ictinaetus malaiensis) & Accipitriformes & Accipitridae & 6 \\
\hline 2 & Walet linchi (Collocalia linchi) & Apodiformes & Apodidae & 37 \\
\hline 3 & Tekukur biasa (Streptopelia chinensis) & Columbiformes & Columbidae & 4 \\
\hline 4 & Cekakak jawa (Halcyon cyanoventris) & Coraciiformes & Alcedinidae & 7 \\
\hline 5 & Cekakak sungai (Todirhampus chloris) & Coraciiformes & Alcedinidae & 13 \\
\hline 6 & Bondol peking (Lonchura punctuluata) & Passeriformes & Estrildidae & 8 \\
\hline 7 & Madu sriganti (Nectarinia jugularis) & Passeriformes & Nectariniidae & 3 \\
\hline 8 & Cinenen kelabu (Orthotomus ruficeps) & Passeriformes & Sylviidae & 1 \\
\hline 9 & Cipoh kacat (Aeghitina tiphia) & Passeriformes & Aegithinidae & 1 \\
\hline 10 & Ciung batu (Myophonus caeruleus) & Passeriformes & Turdidae & 2 \\
\hline 11 & Cucak kutilang (Pycnonotus aurigaster) & Passeriformes & Pycnonotidae & 23 \\
\hline 12 & Kapasan kemiri (Lalage nigra) & Passeriformes & Campephagidae & 1 \\
\hline 13 & Meninting besar (Enicurus leschenaulti) & Passeriformes & Muscicapidae & 13 \\
\hline 14 & Merbah cerukcuk (Pycnonotus goaivier) & Passeriformes & Pycnonotidae & 4 \\
\hline 15 & Prenjak (Prinia inornata) & Passeriformes & Cisticolidae & 3 \\
\hline 16 & Ayam hutan merah (Gallus gallus) & Galliformes & Phasianidae & 1 \\
\hline 17 & Caladi ulam (Dendrocopos macei) & Piciformes & Picidae & 1 \\
\hline \multicolumn{7}{l}{ Total } & 7 & 15 & $\mathbf{1 2 8}$ \\
\hline
\end{tabular}

Field observations showed that the birds found consisted of several orders, including Galliformes, Accipitriformes, Apodiformes, Piciformes, Coraciiformes and Passeriformes. Several sightings documentation results can be seen in the picture are as follow.

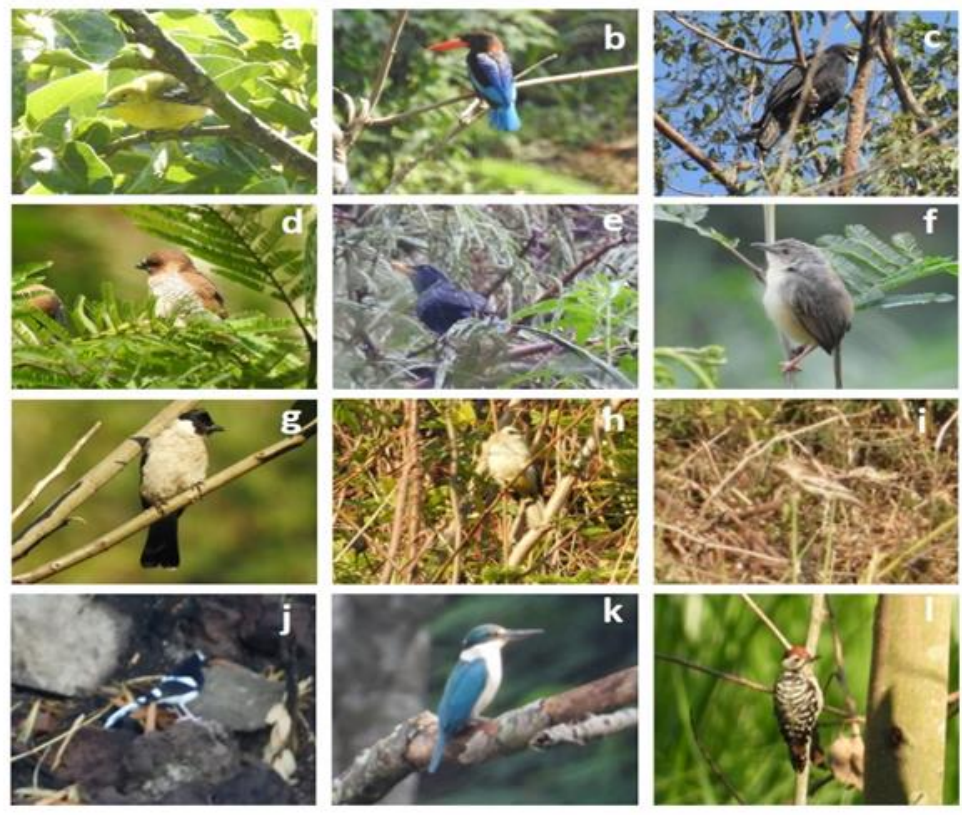

Figure 3. Some of the best observed species in Coban Tarzan; a. Cipoh kacat (Aeghitina tiphia), b. Cekakak jawa (Halcyon cyanoventris), c. Elang hitam (Ictinaetus malaiensis), d. Bondol peking (Lonchura punctulata), e. Ciung batu siul (Myophonus caeruleus), f. Prenjak (Prinia inornata), g. Cucak kutilang (Pycnonotus aurigaster), h. Merbah cerukcuk (Pycnonotus goiavier), i. Kapasan kemiri (Lalage nigra), j. Meninting besar (Enicurus leschenaulti), k. Cekakak sungai (Todiramphus chloris), dan I. Caladi ulam (Dendrocopos macei). 
Table 4. Comparison of Diversity, Evenness and Dominance Index

\begin{tabular}{lll}
\hline \multicolumn{1}{c}{ Parameter } & Coban Tarzan & Coban Kodok \\
\hline Overall Abundance & 144 & 128 \\
\hline Species Richness & 17 & 17 \\
\hline Diversity Index $\left(\mathrm{H}^{\prime}\right)$ & 2.13 & 2.25 \\
\hline Evenness Index $(\mathrm{E})$ & 0.83 & 0.85 \\
\hline Dominance Index $(\mathrm{D})$ & 0.17 & 0.15 \\
\hline
\end{tabular}

Table 5. Comparison of environmental parameters in Coban Tarzan and Coban Kodok

\begin{tabular}{lll}
\hline Parameter & Location & \\
\hline & Coban Tarzan & Coban Kodok \\
\hline Temperature & $21^{\circ} \mathrm{C}$ & $19^{\circ} \mathrm{C}$ \\
\hline Humidity & $75 \%$ & $80 \%$ \\
\hline Water $\mathrm{pH}$ & 8.8 & 8.3 \\
\hline Height & 795 asl & 1039 asl \\
\hline
\end{tabular}

Table 6. Variations in bird diet and bird conservation status in Coban Tarzan and Coban Kodok

\begin{tabular}{|c|c|c|c|c|c|c|}
\hline No. & Local Name (Species Name) & $\begin{array}{l}\text { Coban } \\
\text { Tarzan }\end{array}$ & $\begin{array}{l}\text { Coban } \\
\text { Kodok }\end{array}$ & Food & $\begin{array}{l}\text { IUCN } \\
\text { status } \\
\end{array}$ & LHK Status ${ }^{1}$ \\
\hline 1 & Ayam hutan merah (Gallus gallus) & $\mathrm{V}$ & $\mathrm{V}$ & $\mathrm{O}$ & LC & Not protected \\
\hline 2 & Bentet kelabu (Lanius schach) & $\mathrm{V}$ & - & $\mathrm{I}$ & $\mathrm{LC}$ & Not protected \\
\hline 3 & Bondol Jawa (Lonchura leucogastroides) & $\mathrm{V}$ & - & G. & $\mathrm{LC}$ & Not protected \\
\hline 4 & Bondol peking (Lonchura punctuluata) & - & $\mathrm{V}$ & G. & $\mathrm{LC}$ & Not protected \\
\hline 5 & Caladi Tilik (Dendrocopos moluccensis) & $\mathrm{V}$ & - & $\mathrm{I}$ & $\mathrm{LC}$ & Not protected \\
\hline 6 & Caladi ulam (Dendrocopos macei) & - & $\mathrm{V}$ & $\mathrm{I}$ & $\mathrm{LC}$ & Not protected \\
\hline 7 & Cekakak jawa (Halcyon cyanoventris) & $\mathrm{V}$ & $\mathrm{V}$ & $\mathrm{I}, \mathrm{C}$ & $\mathrm{LC}$ & Not protected \\
\hline 8 & Cekakak sungai (Todirhampus chloris) & $\mathrm{V}$ & $\mathrm{V}$ & $\mathrm{I}, \mathrm{C}$ & LC & Not protected \\
\hline 9 & Cinenen kelabu(Orthotomus ruficeps) & - & $\mathrm{V}$ & 1 & $\mathrm{LC}$ & Not protected \\
\hline 10 & Cipoh kacat (Aegithina tiphia) & - & $\mathrm{V}$ & $\mathrm{I}$ & LC & Not protected \\
\hline 11 & Ciung batu (Myophonus caeruleus) & $\mathrm{V}$ & $\mathrm{V}$ & $\mathrm{I}, \mathrm{F}, \mathrm{C}$ & $\mathrm{LC}$ & Not protected \\
\hline 12 & Cucak kutilang (Pycnonotus aurigaster) & $\mathrm{V}$ & $\mathrm{V}$ & $\mathrm{I}, \mathrm{F}$ & $\mathrm{LC}$ & Not protected \\
\hline 13 & Elang hitam (Ictinaetus malayensis) & - & $\mathrm{V}$ & $\mathrm{C}$ & $\mathrm{LC}$ & Protected \\
\hline 14 & Elang ular bido (Spilornis cheela) & $\mathrm{V}$ & - & C & $\mathrm{LC}$ & Protected \\
\hline 15 & Kacamata biasa (Zosterops palpebrosus) & $\mathrm{V}$ & - & $\mathrm{I}, \mathrm{F}$ & $\mathrm{LC}$ & Not protected \\
\hline 16 & Kadalan Birah (Phaenicophaeus curvirostris) & $\mathrm{V}$ & - & $\mathrm{I}, \mathrm{C}$ & LC & Not protected \\
\hline 17 & Kapasan kemiri (Lalage nigra) & $\mathrm{V}$ & $\mathrm{V}$ & $\mathrm{I}, \mathrm{F}$ & $\mathrm{LC}$ & Not protected \\
\hline 18 & Madu Sriganti (Nectarinia jugularis) & $\mathrm{V}$ & $\mathrm{V}$ & $\mathrm{N}, \mathrm{I}$ & $\mathrm{LC}$ & Not protected \\
\hline 19 & Meninting besar (Enicurus leschenaulti) & - & $\mathrm{V}$ & $\mathrm{I}$ & $\mathrm{LC}$ & Not protected \\
\hline 20 & Merbah cerucuk (Pycnonotus goaivier) & $\mathrm{V}$ & $\mathrm{V}$ & IF & $\mathrm{LC}$ & Not protected \\
\hline 21 & Prenjak (Prinia inornata) & - & $\mathrm{V}$ & $\mathrm{I}$ & $\mathrm{LC}$ & Not protected \\
\hline 22 & Sepah (Pericrocotus cinnamo m eus) & $\mathrm{V}$ & - & $\mathrm{I}$ & $\mathrm{LC}$ & Not protected \\
\hline 23 & Tekukur biasa (Streptopelia chinensis) & $\mathrm{V}$ & $\mathrm{V}$ & $\mathrm{G}, \mathrm{F}$ & $\mathrm{LC}$ & Not protected \\
\hline 24 & Walet linchi (Collocalia linchi) & $\mathrm{V}$ & $\mathrm{V}$ & 1 & $\mathrm{LC}$ & Not protected \\
\hline 13 & Elang hitam (Ictinaetus malayensis) & - & $\mathrm{V}$ & $\mathrm{C}$ & $\mathrm{LC}$ & Protected \\
\hline
\end{tabular}

${ }^{1}$ Based on the Regulation of the Minister of Environment and Forestry of the Republic of Indonesia Number P.106/ MENLHK / SETJEN / KUM.1/12/2018.

Description: F: Frugivore, G: Granivore, I: Insectivore, C: Carnivore; N: Necta rivora, O = Omnivora 


\section{DISCUSSION}

Based on Table 1 and Table 2, it can be observed that the number of species in each coban (Waterfall area) was the same as many as 17 , but there are slight differences in species composition and total individuals observed. One species that was only observed in one location was the type Enicurus leschenaultia. This species is commonly found in rocky contoured plateaus and is often found making nests in rocky holes in the cliffs around rivers. This reason can be used as a reference why the species was only found at Coban Kodok, but not at Coban Tarzan, because in its natural form, Coban was generally flat and dominated by soil and grass, while the habitat type in Coban Kodok was more varied, and one of them is rock cliffs. This is as stated by Crozier and Niemi 2003; Davidar et al. 2001; and Welty, 1982; said that that habitat diversity influenced bird species diversity. The most abundant species in the two research locations was the Collocalia linchi as many as 37 individuals were observed. This species is cosmopolitan, so that its presence in the two research locations is the most dominant. In addition to these species, Pycnonotus aurigaster species were also cosmopolitan, and are the dominant species in Coban Tarzan as many as 37 individuals, while in Coban Kodok, Pycnonotus aurigaster species are in the second rank of 23 individuals.

Some of the very few avifauna species observed in Coban Tarzan are Dendrocopos moluccensis, Halcyon cyanoventris and Phaenicophaeus curvirostris (one individual). While the species with the least encounters in Coban Kodoks were Gallus gallus, Dendrocopos macei, Orthotomus ruficeps, Aeghitina tiphia, and Lalage nigra (one individual).

Based on the results of table 4 analysis, it was known that although the two research locations found the same number of species, there are slight differences in the index of diversity, evenness, and dominance. Overall can be said that the Coban Kodok teritory has avifauna population were slightly better compared to that of the Coban Tarzan. This can be seen from the indication of the diversity index value in Coban Kodok (2.254) which is higher than in the Coban Tarzan area $(2,132)$, which means that overall, Coban Kodok has better diversity than Coban Tarzan.

In addition, the evenness value of the Coban Kodok area (0.8508) has a higher value than the Coban Tarzan (0.8296), meaning that the distribution of bird populations between species was more even, the higher the evenness index value can indicate better community structure and population distribution. The Evenness Index value will affect the Dominance value found at each location, because the Evenness value will be inversely proportional to the Dominance value. The dominance index on Coban Kodok (0.1492) showed a smaller number than the Coban Tarzan dominance index (0.1704). This results showed that the level of dominance in Coban Kodok was better because the lower the dominance value, the smaller the community component that controls the location, thus indicating a more ideal community structure. The values of diversity, evenness, and dominance in an area can be different because of several factors. One of the most influencing factors is the diversity of microhabitat in the area, because microhabitat will affect the biotic and abiotic components in a specific area.

The more diverse the microhabitat there is in an area, the more diverse these factors will be. The more diverse organisms that can live there, because different microhabitats will provide different abiotic factors, and will lead to different feed availability both in quantitative and qualitative terms, which in turn will invite different Avifauna due to differences in the "menu" of the feed. At Coban Tarzan, the majority of the habitats around the Watershed (DAS) have been modified for natural tourism purposes by local managers. So that the available habitat types tend to be uniform. Unlike the premises Coban Kodok DAS environment is still a lot that has not changed. Although several plantations and rice fields were found, however, there were 
still many areas that still had land forms and natural vegetation compositions. In addition, some areas that have been turned into fields and plantations on the one hand have a positive value because they add to the type of microhabitat in the area so that it is possible to become attractants for species that previously did not live there. The quality of the Coban Kodok environment which is known to be better is also supported by the life-supporting abiotic factors as shown in Figure 5. So that from all these supporting factors, Coban Kodok has better diversity, evenness, and dominance values.

Overall conservation status of birds obtained either in Coban Coban Tarzan and the Kodok by IUCN and BirdLife International (2020) were on low risk status (Least Concern), while based on the Regulation of the Minister of Environment d late Forestry of the Republic of Indonesia Number p.106 / MENLHK / Secretariat / KUM.1 / 12/2018 (2018), there were 2 protected bird species that were successfully observed in two observation locations, namely; Crested serpent eagle (Spilornis cheela) (see Figure 2e) and Black Eagle (Ictinaetus malaiensis (Figure 3C).

The effort to understand Allah's creation, including birds, is something very noble. Because with that knowledge humans will take a lot of lessons. Allah SWT said in QS al-An'am verse 38.

وما من دآبة في الأرض و لا طائر يطير بجناحيه إلا أمم

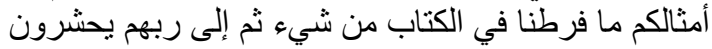
Meaning: "And there are no animals on the earth and no birds that fly with their two wings, but the people (also) like you. We did not neglect anything in the Scriptures, then it was to God that they were gathered".

Emphasis on the comprehensive coverage of the above verse is necessary, because it may be that temporarily or even many people do not realize the essence revealed by the Koran, namely that sea, land and air animals are human beings like humans (Shihab 2002). Each type of animal has its own rules, such as reproduction, way of life, interaction, food, and all the affairs of life. It is Allah Who created it as He created you, giving it sustenance as if it was giving you sustenance, which is in Allah's knowledge and destiny which includes everything. Another opinion says that these animals are like you in terms of dhikr to Allah and as an indication of His greatness.

(We have neglected anything in the Bible) That is, whether it is from your affairs or the affairs of these animals. What is meant by al-Kitab is lauhul mahfudz, Allah has determined in it all events.

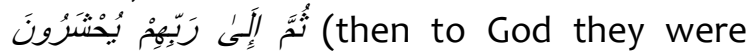
gathered) Namely the animals. This verse indicates that the animals will be raised and gathered together just as humans will be gathered. Abu Hurairah said: "There is no reptile or bird unless they will be resurrected on the Day of Judgment, then they will qishash each other, until the hornless animal will qishash the horned animal (Tafsirweb, 2019).

The existence of birds with various types and activities is actually a proof of Allah's power. Even in another verse Allah Ta'ala says,

$$
\begin{aligned}
& \text { ألم تر أن الله يسبح له من في السماوات و الأرض و الطير } \\
& \text { صافات كل قد علم صلاته وتنسبحه و الله عليم بما بفعلون }
\end{aligned}
$$
what is in the heavens and on the earth and (also) birds by spreading their wings. Each one has known (the way) of worship and prayer beads, and Allah knows best what they do. "(Surah An-Nuur: 41).

Az Zuhaili stated that: Allah Subhaanahu wa Ta'aala reminds His servants of His majesty, the perfection of His power and the need for all creatures to Him and to worship Him. Both living and inanimate things. Each creature knows how to pray and prayer beads to Allah with inspiration from Allah according to their respective circumstances. The word "Qad 'alima shalaatahu wa tasbiihah" can also return to Allah, so that it means that Allah knows the prayers and tasbih of each of His creatures. This is like in another verse which says, "Seven heavens, the earth and all that is in it praises 
Allah and there is nothing but praise Him, but you do not understand their tasbih. Indeed, He is Most Forgiving, Most Forgiving. "(Trans. Al Israa ': 44) He knows all their deeds and none of their deeds are vague, and He will reward them (Tafsirweb, 2019).

From the explanation of the above verse it can be understood that birds are like humans in that the purpose of their creation in this world is solely to worship and serve Him in a way that is inspired by them. Seeing the very specific and important role of birds for the ecosystem, humans should be grateful to their creators by preserving their existence.

\section{CONCLUSION}

Based on a review of the results and discussion, it can be concluded that the number of Avifauna species (species richness) observed in Coban Kodok was 17 species with a total abundance of 128 individuals. Meanwhile, the species richness observed in Coban Tarzan was 17 species with different compositions, and the abundance was 142 . Then the value of Diversity, Evenness, and Dominance index in Coban Kodok is $2.254 ; 0.8508 ; 1,492$. While at Coban Tarzan was 2,132; 0.8296; 0.1704 respectively. Based on bird species observed, all bird species have a low risk conservation status according to IUCN RedList and BirdLife International.

\section{SUGGESTION}

Suggestions for further research: It is suggested that the research be continued for the rainy season, to compare the composition, diversity, evenness, and dominance between seasons, because this study only took the final data of the dry season. With several birds that are small and sensitive to human presence, it is suggested that the researcher complete the supporting equipment for observation to maximize the documentation for the identification process and research evidence. Avifauna data collection should be carried out continuously as a monitoring effort due to changes in habitat and land which are currently rife in various natural tourism areas. Thus obtained the latest information about the status of the population partially, as a support for the status of the global population.

\section{ACKNOWLEDGEMENT}

The author would like to thankto the SIMAPEL UIN Malang who have funded this research. Thanks were given to the Coban Tarzan and Coban Kodok biodiversity exploration team including M. Asmuni Hasyim, Bayu Agung Prahardika, Dinda Tilalanisari Firizki, Widi Muhammad LDS, Lisana Sidqi Aliya, and M. Haidar Nazarudin. May Allah gives them the best rewards.

\section{REFERENCES}

Alikodra, H.S. 1990. Wildlife Management Volume 1. Bogor: Bogor Agricultural University

Bibby, C.J., M. Jones, SJ. Marsden, R. Sozer, V. Nijman, 2000. Teknik-Teknik Ekspedisi Lapangan: Survey Burung. Birdlife International Indonesia Programme, Bogor.

Calimpong, D.M.T \& OM, Nuneza. 2015. Avifaunal Diversity of Bega Watershed, Prosperidad, Agusan Del Sur, Philippines. Journal of Biodiversity and Environmental Sciences (JBES), 6 (4):.385-400

Crozie, G.E. and Niemi, G.J.2003. Using Patch and Landscape Variables To Model Bird Abundance In a Naturally Heterogenous Landscape. Can. J. Zool 81: 441-452.

Davidar, P, Yoganand, K, Garsch T. 2001. Distribution of forest bird in Andom Island importana of leg habitat. Journal of Biogeography 28: 666-671.

Ghifari,B., Hadi M., Tarwotjo, 2016. Diversity and Abundance of Bird Species in Semarang City Park, Central Java. Journal of Biology, Volume 5 No 4, October 2016 p. 24-31

Hernowo, JB and Prasetyo, LB. 1989. Conception of green open space in cities as a supporter of bird 
conservation. Conservation Media. Vol.2

no.4.

Islam, M.S. and Sofiah, B.S. 2014. Birds Mention in the Holy Qur'an and their Role in the Natural Ecosystem. Australian Journal of Basic and Applied Sciences, 8(6) April 2014, Pages: 293306. ISSN:1991-8178. Journal home page: www.ajbasweb.com

IUCN and BirdLife International : https://www.birdlife.org/news/tag/iucn -red-list

Kementerian Lingkungan Hidup dan Kehutanan 2018. Jenis Tumbuhan Dan Satwa Yang Dilindungi P.106 / Menlhk / Secretariat / Kum.1 / 12/2018: http://ksdae.menlhk.go.id/peraturan.ht $\underline{\mathrm{ml}}$

Kumpulan Tafsir Kontemporer online: https://tafsirweb.com/2162-quran-suratal-anam-ayat-38.html

McKinnon et al., 2010 Mackinnon, J., Phillipps, K. and Balen, BV 2010. Birds in Sumatra, Java, Bali and Kalimantan. Bogor: LIPIIndonesian Bird.

Nugroho, A. 2008. Bird Diversity in Geleang Island, Arimunjawa National Park, Bird Island. (Thesis). Semarang: Biology Study Program, Semarang State University. Wibowo

Shihab, Q. 2002. Tafsir Al-Misbah . Jakarta: Heart Lantera

Sukmantoro W., and Irham, M. 2007. List of Indonesian Birds. Bogor: Indonesia Ornithologists' Union

Welty, J.C.1982. The Life of Bird. Saunders College Publishing. Philadelphia

Wisnubudi, G. 2009. The use of vegetation strata by birds in the tourist area of Mount Halimun-Salak National Park. Journal of Vis Vitalis. Vol.02 No.2. 